\title{
Effect of Organic Mineral Supplementation on The Egg Quality of Semi-Heavy Layers in Their Second Cycle of Lay'
}

Author(s)
Saldanha ESPB2
Garcia $\mathrm{EA}^{3}$
Pizzolante $C C^{4}$
Faittarone $\mathrm{ABG}^{2}$
Sechinato $A \mathrm{da}^{5}$
Molino $A B^{2}$
Laganá $\mathrm{C}^{4}$
1 Part of the thesis presented by the first
author at UNESP / Botucatu as one of the
requisites to obtain the title of Ph.D. in Animal
Science.
2 Students of the Post-Graduation Program
in Animal Production FMVZ/UNESP,
Botucatu.
3 Professor of the Department of Animal
Production - FMVZ/UNESP, Botucatu.
4 Researcher of Agência Paulista de Tecnologia
dos Agronegócios - APTA/SAA.
5 Tortuga Companhia Zootécnica Agrária.

Mail Address

Érika Salgado Politi Braga Saldanha Unidade de Pesquisa e Desenvolvimento de Brotas - APTA/SAA

Brotas, SP, Brasil

phone: 551436531102

e-mail: erikapsaldanha@apta.sp.gov.br erikapsaldanha@yahoo.com.br

\section{Keywords}

Eggshell quality, forced molting, mineral supplementation, yolk.

\section{ABSTRACT}

This study was carried out to evaluate the effects of dietary trace mineral levels and sources on egg quality parameters of second-cycle semi-heavy layers. A number of 36072 -week-old layers were submitted to forced molting. Upon return of lay ( 83 weeks of age), birds were distributed according to a completely randomized experimental design of six treatments with six replicates of 10 birds each. The control treatment consisted of $0.10 \%$ dietary supplementation of trace minerals from inorganic sources, which was proportionally replaced by five levels $(110,100,90,80,70 \%)$ of an organic trace mineral supplement containing $30,30,40,6,0.61$, and $0.3 \mathrm{~g} / \mathrm{kg}$ product of $\mathrm{Zn}, \mathrm{Fe}, \mathrm{Mn}, \mathrm{Cu}$, $\mathrm{I}$, and Se, respectively. All diets contained equal protein, energy, and amino acid levels. Every 28 days of the experimental period (112 days) four eggs per replicate were collected for egg quality evaluation. The following parameters were evaluated: specific gravity, yolk, albumen and eggshell percentages, yolk index, Haugh units, and eggshell thickness and breaking strength. One sample per replicate, consisting of the pool of the yolks of three eggs collected at the end of each experimental period, was used to assess protein and mineral ( $\mathrm{Ca}, \mathrm{P}, \mathrm{Cu}, \mathrm{Fe}, \mathrm{Mn}$, and $\mathrm{Zn})$ contents. The results were submitted to ANOVA, and means to the test of Tukey at $5 \%$ significance level. The evaluated trace mineral levels and sources did not influence any of the studied egg quality parameters. It was concluded that reducing organic trace mineral supplementation in up to $70 \%$ relative to $100 \%$ inorganic trace mineral supplementation does not affect egg parameters and therefore, can be applied to the diet of semi-heavy layers in their second cycle of lay.

\section{INTRODUCTION}

Forced molting of layers has been increasingly used in Brazil as it results in high egg production and large eggs, which consequently demands the adjustment of dietary nutritional levels. Despite the intensive use of a second laying cycle, there is little information on the nutritional levels recommended for layers in this phase; in general, the nutritional requirements of layers at the end of the first cycle of lay are applied with slight reduction of the nutritional levels.

Improving mineral bioavailability by using organic sources may be an option to adjust nutritional levels. Both large and trace minerals added to poultry diets traditionally derive from inorganic sources, such as oxides, sulfates, chlorides, carbonates, and phosphates. In practice, excessive levels of minerals, such as $\mathrm{Zn}, \mathrm{Cu}, \mathrm{Fe}$, and $\mathrm{Mn}$, have been used to prevent deficiencies (Bertechini, 2003) caused by possible interactions among these minerals and other dietary components, rendering them unavailable to the bird's digestive system (Mabe et al., 2003). 
Organic trace minerals are compounds consisting of metal ions bound to organic substances, including amino acids, peptides, or polysaccharide complexes, providing these ions with high biological availability, stability, and solubility (Vieira, 2004). As a function of these characteristics, these minerals are more bioavailable, and are readily transported and absorbed in the intestines. In addition, they are more stable and biochemically protected against unfavorable reactions with other dietary components, which may reduce their absorption rates (Close, 1998).

Some studies conducted to determine the bioavailability of organic trace mineral sources showed that these were more available that the inorganic sources (Ammerman et al.,1998; Aoyagi \& Baker, 1993; Spears et al., 1992; Baker et al., 1991).

Lundeen (2001) added organic trace minerals to the diet of 40- to 60-week-old layers and observed higher eggshell percentage, stronger eggshells, and lower number of cracked eggs. A significant reduction of eggshell defects and higher eggshell breaking strength were observed by Moreng et al. (1992) when layer diets were supplemented with organic zinc as compared with its inorganic source.

Layer nutrition, in addition to affecting physical egg quality (size, percentages of the egg components, eggshell strength), may influence egg chemical composition (Franco \& Sakamoto, 2005). The egg consists of four main components: eggshell membrane, eggshell, yolk, and albumen, with the three latter accounting for 10,30 , and $60 \%$ of total egg weight, respectively.

The yolk contains 12 to $16 \%$ protein and 1.0 to $2.0 \%$ minerals, whereas the albumen contains $10 \%$ and 0.6 to $0.9 \%$, respectively (Madrid et al., 1996). The yolk consists of approximately $50 \%$ solids, and it is a solution of particles in a protein suspension with high mineral content, particularly of iron and phosphorus, and its composition may be influenced by the diet (Rose, 1997).

According to Cao et al. (1996), layers have high dietary iron requirements as each egg contains approximately $1.5 \mathrm{mg}$ iron in the yolk, which represents $25 \%$ of the iron reserves available in the liver. Paik (2001) observed an increase in yolk iron content when layers were fed an iron-methionine complex as compared to those fed inorganic iron.

Selenium metabolism in poultry has been frequently studied in the last 30 years, but it is still not clear if selenium is incorporated in the eggshell and/or yolk and if this depends on dietary selenium supply. According to Franco \& Sakamoto (2005), selenium supplementation in layer feeds results in higher egg selenium content, favoring higher selenium ingestion by egg consumers. In addition, higher egg selenium content allows the maintenance of egg internal quality during storage.

The objective of the present study was to evaluate the effects of detary mineral supplement sources and levels on the internal and external egg quality of semiheavy layers in their second cycle of lay.

\section{MATERIAL AND METHODS}

The experiment was carried out at the Unit of Research and Development of Brotas of the Agency of Agribusiness Technology of the Agriculture Department of the State of São Paulo for 112 days (4 cycles of 28 days).

A number of $360 \mathrm{Hy}$-Line Brown semi-heavy layers with 72 weeks of age at the end of the first cycle of lay was used. Birds were submitted for forced molting using the conventional method - 14 days of fasting and then feeding ground corn for 28 days. At 83 weeks of age, after lay was resumed, birds were distributed into the experimental treatments.

Birds were housed in a layer house with two double and overlapping batteries of cages and a central aisle. Galvanized iron cages were $1.00 \mathrm{~m}$ long x $45 \mathrm{~cm}$ deep $x 40 \mathrm{~cm}$ high. Each cage had two internal compartments, with a capacity of five birds each, therefore allowing 10 birds per cage to be housed. Each cage was considered an experimental unit.

The cages were equipped with nipple drinkers and wood trough feeders placed along the front of the cages. Feed was offered ad libitum in the morning and in the afternoon. A lighting program of 17 hours of light daily was adopted. Daily environmental temperature was recorded using a maximum-minimum temperature thermometer located in the center of the house.

A completely randomized experimental design with six treatments with six replicates of 10 birds each was applied. The experimental treatments consisted of the dietary inclusion of $100 \%$ inorganic mineral supplement (IM), or organic mineral (OM) supplement included at $110,100,90,80$, or $70 \%$ of IM levels. Both inorganic and organic supplements were formulated with $\mathrm{Zn}, \mathrm{Mn}$, $\mathrm{Cu}, \mathrm{Fe}, \mathrm{Se}$, and I.

In the experimental diet of the $100 \%$ IM treatment, $0.10 \%$ of the mineral supplement was added. In order to supply the same mineral concentration as the $0.10 \%$ inorganic mineral supplementation, $0.18 \%$ organic 


\section{Saldanha ESPB, Garcia EA, Pizzolante CC, Faittarone ABG, Sechinato A da, Molino AB, Laganá C}

mineral supplement was added to the feed, corresponding to the $100 \%$ OM treatment. The other $\mathrm{OM}$ inclusion levels were calculated based on this value, and the inclusion of $0.198,0.162,0.144$, and $0.126 \%$ OM supplement corresponded to the treatments $110,90,80$, and $70 \% \mathrm{OM}$, respectively. Mineral supplements were formulated according to the recommendations of the company Tortuga $^{\circledR}$, with guaranteed levels to supply the nutritional requirements of layers at the end of lay. Table 1 shows the composition of the trace mineral supplements, and Table 2 their inclusion levels in the experimental diets.

The formulation of the experimental diets (Table 3), based on corn and soybean meal, was adapted from
Rostagno et al. (2000). Diets were different only as to $\mathrm{Zn}, \mathrm{Fe}, \mathrm{Mn}, \mathrm{Cu}, \mathrm{I}$, and Se levels.

At the end of each experimental period of 28 days, four eggs from each experimental unit were collected to evaluate the following parameters: specific gravity, yolk, albumen and eggshell percentages, yolk index, Haugh units, and eggshell thickness and breaking strength.

Intact eggs were identified, individually weighed in a digital-precision scale $(0.01 \mathrm{~g})$, and submitted to specific gravity assessment using the method of egg immersion in saline solution. Nine solutions, with densities between 1.060 a 1.100 , with graded variation of 0.005 between each solution, were prepared. Specific gravities were determined using a densitometer.

\begin{tabular}{|c|c|c|c|c|c|c|}
\hline \multirow[t]{2}{*}{ Source } & \multirow[b]{2}{*}{$\mathrm{Zn}$} & \multicolumn{4}{|c|}{ Trace minerals $(\mathrm{mg} / \mathrm{kg})$} & \multirow[b]{2}{*}{ Se } \\
\hline & & $\mathrm{Fe}$ & $\mathrm{Mn}$ & $\mathrm{Cu}$ & $T$ & \\
\hline Inorganic trace minerals & 54.00 & 54.00 & 72.00 & 10.00 & 0.61 & 0.30 \\
\hline Organic trace minerals & 30.00 & 30.00 & 40.00 & 6.00 & 0.61 & 0.30 \\
\hline
\end{tabular}

\begin{tabular}{|c|c|c|c|c|c|c|c|}
\hline \multirow[t]{2}{*}{ Treatments } & \multirow{2}{*}{$\begin{array}{c}\text { Feed } \\
\text { inclusion (\%) }\end{array}$} & \multicolumn{6}{|c|}{ Trace minerals $(\mathrm{mg} / \mathrm{kg})$} \\
\hline & & $\mathrm{Zn}$ & $\mathrm{Fe}$ & $M n$ & $\mathrm{Cu}$ & $T$ & Se \\
\hline $100 \% \mathrm{IM}$ & 0.100 & 54.00 & 54.00 & 72.00 & 10.00 & 0.61 & 0.30 \\
\hline $110 \%$ OM & 0.198 & 59.40 & 59.40 & 79.20 & 11.88 & 1.21 & 0.59 \\
\hline $100 \% \mathrm{OM}$ & 0.180 & 54.00 & 54.00 & 72.00 & 10.80 & 1.10 & 0.54 \\
\hline $90 \%$ OM & 0.162 & 48.60 & 48.60 & 64.80 & 9.72 & 0.99 & 0.49 \\
\hline $80 \%$ OM & 0.144 & 43.20 & 43.20 & 57.60 & 8.64 & 0.88 & 0.43 \\
\hline $70 \%$ OM & 0.126 & 37.80 & 37.80 & 50.40 & 7.56 & 0.77 & 0.38 \\
\hline
\end{tabular}

Table 3 - Ingredient and calculated compositions of the experimental diets of semi-heavy layers in their second cycle of lay supplemented with different trace mineral sources and levels.

\begin{tabular}{|c|c|c|c|c|c|c|}
\hline \multirow[t]{2}{*}{ Ingredients (\%) } & \multirow[b]{2}{*}{$100 \mathrm{IM}$} & \multicolumn{5}{|c|}{ OM supplementation level $(\%)^{1}$} \\
\hline & & 110 & 100 & 90 & 80 & 70 \\
\hline Ground corn & 65.41 & 65.32 & 65.33 & 65.35 & 65.37 & 65.39 \\
\hline Soybean meal $45 \%$ & 20.24 & 20.24 & 20.24 & 20.24 & 20.24 & 20.24 \\
\hline Wheat midds & 3.66 & 3.66 & 3.66 & 3.66 & 3.66 & 3.66 \\
\hline Dicalcium phosphate & 1.29 & 1.29 & 1.29 & 1.29 & 1.29 & 1.29 \\
\hline Soybean soapstock & 1.00 & 1.00 & 1.00 & 1.00 & 1.00 & 1.00 \\
\hline Limestone & 7.73 & 7.73 & 7.73 & 7.73 & 7.73 & 7.73 \\
\hline Mineral suppl & $0.100 *$ & $0.198 * *$ & $0.180 * *$ & $0.162 * *$ & $0.144 * *$ & $0.126 * *$ \\
\hline Vitamin suppl $(* \star \star)$ & 0.10 & 0.10 & 0.10 & 0.10 & 0.10 & 0.10 \\
\hline Salt $(\mathrm{NaCl})$ & 0.35 & 0.35 & 0.35 & 0.35 & 0.35 & 0.35 \\
\hline DL-methionine & 0.12 & 0.12 & 0.12 & 0.12 & 0.12 & 0.12 \\
\hline Total & 100.00 & 100.00 & 100.00 & 100.00 & 100.00 & 100.00 \\
\hline \multicolumn{7}{|l|}{ Calculated composition } \\
\hline ME (kcal/kg feed) & 2790 & 2790 & 2790 & 2790 & 2790 & 2790 \\
\hline Crude protein (\%) & 15.50 & 15.50 & 15.50 & 15.50 & 15.50 & 15.50 \\
\hline Calcium (\%) & 3.50 & 3.50 & 3.50 & 3.50 & 3.50 & 3.50 \\
\hline Avail. phosphorus (\%) & 0.34 & 0.34 & 0.34 & 0.34 & 0.34 & 0.34 \\
\hline Methionine (\%) & 0.35 & 0.35 & 0.35 & 0.35 & 0.35 & 0.35 \\
\hline Methionine + cystine (\%) & 0.64 & 0.64 & 0.64 & 0.64 & 0.64 & 0.64 \\
\hline Lysine (\%) & 0.74 & 0.74 & 0.74 & 0.74 & 0.74 & 0.74 \\
\hline
\end{tabular}

*Inorganic trace mineral supplement, $\mathrm{g} / \mathrm{kg}$ product: zinc $54 \mathrm{~g}$, iron $54 \mathrm{~g}$, manganese $72 \mathrm{~g}$, copper $10 \mathrm{~g}$, iodine $0.61 \mathrm{~g}$, selenium $0.30 \mathrm{~g}$. $* *$ Organic trace mineral supplement, g/ $\mathrm{kg}$ product: zinc $30 \mathrm{~g}$, iron $30 \mathrm{~g}$, manganese $40 \mathrm{~g}$, copper $6 \mathrm{~g}$, iodine $0.61 \mathrm{~g}$, selenium $0.30 \mathrm{~g}$. $* * * V i t a m i n$ supplement, composition per kg product: Vit A 7,520,000 IU, Vit. D3 1,816,000 IU, Vit. E 8400 mg, Vit. K3 1280 mg, Vit. B1 1340 mg, Vit. B2 3000 mg, Vit. B6 $1660 \mathrm{mg}$, Vit B12 $8.000 \mathrm{mg}$, nicotinic acid 20,000 mg, calcium pantothenate $8000 \mathrm{mg}$, folic acid $300 \mathrm{mg}$, biotin $40 \mathrm{mg}$. 
Eggshell breaking strength was assessed in the intact egg using a specific cell coupled to a Texture Analyzer TA.XT plus with Cyl Stainless 2-mm probe code $P / 2$, which recorded the strength $(\mathrm{kgf})$ required to break the eggshell.

In order to determine Haugh units eggs were broken on a flat glass surfaces, and three measurements of albumen height were made used a micrometer in the median region between the external edge and the egg yolk. The average of the obtained values was used in the formula proposed by Card \& Nesheim (1978): HU $=100 . \log \left(\mathrm{H}+7.57-1.7 \mathrm{~W}^{0.37}\right)$, where: $\mathrm{H}=$ albumen height $(\mathrm{mm})$ and $\mathrm{W}=$ egg weight $(\mathrm{g})$. Albumen weight was calculated as result of intact egg weight minus yolk and dry eggshell weights. Albumen percentage was determined by the ratio between albumen and egg weights multiplied by 100 .

Yolk percentage was calculated as the ratio between yolk and egg weights multiplied by 100 . Yolk quality was assessed by measuring yolk height (YH) and yolk width (YW), and yolk index $(\mathrm{YI})$, was calculated as the ration between those parameters as $\mathrm{YI}=\mathrm{YH}$ / YW.

Eggshells were washed under running water, dried in an oven at $60^{\circ} \mathrm{C}$ for 48 hours, and then weighed in a digital scale. Eggshell percentage was calculated as the ration between egg weight and dried eggshell weight. Eggshell thickness was determined in three different regions using a special micrometer, of the brand Mitutoyo, with $0.01-\mathrm{mm}$ precision. These determinations were carried out according to the description of Souza et al. (1984).

Yolk protein and mineral $(\mathrm{P}, \mathrm{Ca}, \mathrm{Cu}, \mathrm{Fe}, \mathrm{Mn}$, and $\mathrm{Zn}$ ) analyses were carried out in the eggs collected at the end of the experimental period. Eighteen eggs were used per treatment. Each sample consisted of a pool of three eggs per experimental unit, totaling six replicates per treatment.
After the separation of the albumen, the three yolks were homogenized and placed in an oven at $60^{\circ} \mathrm{C}$ for 96 hours. After this period, protein content was analyzed by determining total nitrogen content using the method of Kjeldahl according to the A.O.A.C. (1995), and calculating protein percentage by multiplying mean values of nitrogen percentage by 6.25. Mineral contents ( $P, C a, C u, F e, M n$, and $Z n$ ) were determined according to the norms of the A.O.A.C. (1995).

The results were compared by analysis of variance for balanced data, and means were compared by the test of Tukey, using Sisvar statistical package as described by Ferreira (2000). A 5\% significance level was considered.

\section{RESULTS AND DISCUSSION}

Table 4 presents the mean egg quality results of semi-heavy layers in their second cycle of lay fed diets with different trace mineral ( $\mathrm{Zn}, \mathrm{Fe}, \mathrm{Mn}, \mathrm{Cu}, \mathrm{l}$, and $\mathrm{Se}$ ) sources and levels. Internal egg quality, represented by the parameters yolk percentage, yolk index, albumen percentage, and Haugh units, was not significantly influenced by the treatments.

These results may be explained by the excessive supplementation levels of the evaluated trace minerals. The studied trace minerals levels, including those obtained by organic sources, may have been higher than those required to optimize egg quality. According to Bertechini (2003), trace mineral inclusion levels in layer diets currently applied in the Brazilian market are higher than those required by the birds. As in the present experiment the inclusion of organic trace minerals was calculated relative to the level of inclusion of inorganic trace minerals, the organic sources supplied higher levels than those required.

Many research studies have been carried out on

\begin{tabular}{|c|c|c|c|c|c|c|c|}
\hline \multirow[t]{2}{*}{ Parameters } & \multirow{2}{*}{$\begin{array}{c}\text { IM (\%) } \\
100\end{array}$} & \multicolumn{5}{|c|}{ OM (\%) } & \multirow[t]{2}{*}{ CV $(\%) *$} \\
\hline & & 110 & 100 & 90 & 80 & 70 & \\
\hline Yolk (\%) & 24.99 & 24.62 & 24.48 & 24.24 & 24.67 & 24.67 & 3.59 \\
\hline Yolk index & 0.441 & 0.442 & 0.443 & 0.447 & 0.443 & 0.443 & 2.02 \\
\hline Albumen (\%) & 65.92 & 66.24 & 66.30 & 66.62 & 66.03 & 66.36 & 1.41 \\
\hline Haugh units & 86.50 & 87.80 & 86.75 & 86.80 & 87.63 & 88.03 & 3.71 \\
\hline Eggshell (\%) & $9.08 a b$ & $9.15 a b$ & $9.22 a b$ & $9.14 a b$ & $9.29 a$ & 8.96b & 2.78 \\
\hline Eggshell thickness (mm) & 0.396 & 0.398 & 0.403 & 0.408 & 0.405 & 0.397 & 2.91 \\
\hline$S G * *$ & $1.085 a b$ & $1.085 a b$ & $1.086 a b$ & $1.085 a b$ & $1.087 a$ & $1.084 b$ & 0.16 \\
\hline Breaking strength ( $\mathrm{gF}$ ) & 2622 & 2673 & 2699 & 2776 & 2657 & 2766 & 5.31 \\
\hline
\end{tabular}

${ }^{*} \mathrm{CV}(\%)=$ Coefficient of variation. ${ }^{*} \mathrm{SG}=$ specific gravity. Means followed by different letter in the same row are different by the test of Tukey $(p<0.05)$. 
the dietary supplementation of inorganic and organic trace minerals, tested either individually or in association. However, literature results relative to the addition of different mineral sources to commercial layer diets are still controversial. The lack of better and significant results in terms of egg quality may be explained not only due to the possible excessive supplementation of trace minerals, but also due to differences in organic sources and levels used in these studies.

Sources of organic trace minerals used individually and/or associated did not have any influence, considering the average obtained during the entire experimental period, on Haugh units (Scatolini, 2007; Sechinato, 2003) or yolk index (Scatolini, 2007). Correia et al. (2000) evaluated the supplementation of organic selenium in layer diets and did not find significant differences in Haugh units, yolk and albumen percentages, or albumen height.

On the other hand, Xavier et al. (2004) observed better egg quality in semi-heavy layers in their second cycle of lay, and concluded that the inclusion of Se, $\mathrm{Zn}$, and $\mathrm{Mn}$ as an organic complex is beneficial in this phase. Rutz et al. (2006) evaluated the eggs of Isa Brown layers in their first cycle of lay and fed organic selenium (particularly selenomethionine), and observed a trend of better yolk and albumen weights, and a consistent improvement of albumen quality, as evaluated by Haugh units, indicating a positive effect of organic selenium on the absorption and/or protection of fat-soluble vitamins. Layers in their second cycle of lay and supplemented with organic trace minerals (Se, Zn e Mn) tended to have higher yolk and albumen weights.

Despite the lack of significant differences among the evaluated trace mineral sources in the present study, organic trace mineral level significantly influenced egg specific gravity and eggshell percentage, with the $80 \%$ organic trace mineral level promoting higher eggshell percentage and specific gravity values as compared to the level of $70 \%$. However, these treatments were not significantly different as compared to the others (Table 4).

The results obtained in the present study are consistent with the findings of Scatolini (2007), Albuquerque (2004), Sechinato (2003), and Mabe et al. (2003), who used diets supplemented with individual and/or associated organic trace minerals and inorganic trace minerals and did not observed any treatment effect on external egg quality.

Organic selenium supplementation was evaluated by Correia et al. (2000), who did not observe significant effect on egg specific gravity or eggshell thickness. On the other hand, Paton \& Cantor (2000) found higher eggshell breaking strength in 80-week-old Babcock layers fed organic selenium.

The supplementation of layer diets with organic $\mathrm{Zn}$ and $\mathrm{Mn}$, according to some authors, has shown beneficial effects on external egg quality. Paik (2001) evaluated organic Zn, Cu, and Mn sources in layer diets, and observed higher specific gravity and eggshell percentage in the eggs of layers fed organic trace minerals, and the association between organic $\mathrm{Zn}$ and $M n$ improved eggshell strength. According to that author, Zn influenced the synthesis of the enzyme carbonic anhydrase, which is essential for eggshell formation.

These results are consistent with those of Klecker et al. (1997), who observed higher breaking strength in the eggs of hens fed $\mathrm{Zn}$ and $\mathrm{Mn}$ proteinate replacing 20 to $40 \%$ of the inorganic forms present in the tested diets. Lundeen (2001) observed better eggshell quality in the eggs of layers supplemented with chelated $\mathrm{Mn}$ and $\mathrm{Zn}$ between 20 and 60 weeks of age.

Isa Brown layers supplemented with organic trace minerals ( $\mathrm{Se}, \mathrm{Zn}$, and $\mathrm{Mn}$ ) tended to have higher eggshell weight (Rutz et al., 2006). According to the authors, the supplementation of layer diets with organic trace minerals improves

Eggshell quality, provided organic $\mathrm{Mn}$ and $\mathrm{Zn}$ are added.

Mean protein percentage and mineral composition of the egg yolk are presented in Table 5 .

The use of inorganic trace mineral sources as compared to organic sources, in the same or different concentrations, did not influence yolk protein content or mineral composition. The results obtained with the supplementation of $70 \%$ organic trace minerals were statistically similar to the treatments with $100 \%$ inorganic trace minerals or $110,100,90$, and $80 \%$ de organic trace minerals, suggesting that the studied levels of trace minerals, including those of organic sources, may be higher than those required by the birds.

Mean yolk percentage and egg weight observed in the present study with 99-week-old Hy-Line Brown layers in their second cycle of lay were $24.61 \%$ and $68.62 \mathrm{~g}$, respectively. The observed yolk mineral concentration (Table 5) was higher as compared to some literature studies (Kuit, 1984; Mabe et al., 2003) possibly as a function of bird age and strain in the present study. Faria et al. (2007) observed that the 
Table 5 - Protein content and mineral composition, on dry matter basis, of the egg yolk of semi-heavy layers in their second cycle of lay fed an inorganic trace mineral supplement (IM) or different levels or an organic trace mineral supplement (OM).

\begin{tabular}{|c|c|c|c|c|c|c|c|}
\hline Treat. & $\begin{array}{c}\text { Protein } \\
(\%)\end{array}$ & $\begin{array}{c}P \\
g / k g\end{array}$ & $\begin{array}{c}\mathrm{Ca} \\
\mathrm{g} / \mathrm{kg}\end{array}$ & $\begin{array}{c}\mathrm{Cu} \\
\mathrm{mg} / \mathrm{kg}\end{array}$ & $\begin{array}{c}\mathrm{Fe} \\
\mathrm{mg} / \mathrm{kg}\end{array}$ & $\begin{array}{c}\mathrm{Mn} \\
\mathrm{mg} / \mathrm{kg}\end{array}$ & $\begin{array}{c}\mathrm{Zn} \\
\mathrm{mg} / \mathrm{kg}\end{array}$ \\
\hline $100 \% \mathrm{IM}$ & 31.10 & 12.03 & 3.00 & 4.00 & 154.00 & 3.00 & 86.00 \\
\hline $110 \% \mathrm{OM}$ & 31.00 & 11.42 & 3.00 & 3.70 & 152.00 & 3.00 & 81.80 \\
\hline $100 \%$ OM & 29.60 & 12.23 & 3.00 & 4.00 & 167.00 & 3.00 & 84.50 \\
\hline $90 \%$ OM & 31.50 & 11.85 & 3.00 & 4.30 & 160.00 & 3.00 & 82.00 \\
\hline $80 \%$ OM & 31.60 & 11.62 & 3.00 & 4.00 & 155.00 & 3.00 & 83.80 \\
\hline $70 \%$ OM & 31.10 & 11.95 & 3.00 & 4.00 & 147.00 & 3.00 & 85.30 \\
\hline Mean & 31.00 & 11.85 & 3.00 & 4.00 & 156.00 & 3.00 & 83.90 \\
\hline$C V *(\%)$ & 5.48 & 6.13 & 0.00 & 22.67 & 12.10 & 0.00 & 9.21 \\
\hline
\end{tabular}

* $\mathrm{CV}(\%)=$ Coefficient of variation.

concentration of solids in the yolk was influenced by strain, with higher values obtained with brown layers. Those authors also reported that the older the bird, the heavier the egg, and the higher the yolk percentage.

In the present study, it was observed that the dietary supplementation of trace minerals, either from organic or inorganic sources, was not sufficient to enrich the egg yolk, as the utilized level of inorganic trace minerals followed the recommendations of the strain's manual, and there was no difference between treatments.

Benites et al. (2005) showed that the diet influences yolk protein, fatty acid, and cholesterol contents. As to minerals, the yolk can be enriched with iron.

Bertechini et al. (2000) found a linear increase $(p<0.05)$ in iron content when a corn and soybean meal diet was supplemented with up to 80 ppm iron (ferrous sulfate). Paik (2001) observed that the use of chelated iron increases in up to $20 \%$ yolk iron content.

Mabe et al. (2003) supplemented a diet based on corn and soybean meal with inorganic or organic trace minerals ( $\mathrm{Zn}, \mathrm{Mn}$, and $\mathrm{Cu}$ ), and observed that, independently of the source, the supplementation of 60,60 , and $10 \mathrm{mg} / \mathrm{kg} \mathrm{Zn,} \mathrm{Mn} \mathrm{e} \mathrm{Cu,} \mathrm{respectively,} \mathrm{as}$ compared to the treatment with no supplementation, increased $(p<0.01) \mathrm{Mn}$ and $\mathrm{Zn}$ yolk concentration, whereas copper concentration was not affected.

Skrivan et al. (2005) used supplemented inorganic $\mathrm{Zn}, \mathrm{Fe}$, and $\mathrm{Cu}$ individually or associated in layer diets, and found that the supplementation of the basal diet with iron increased yolk iron concentration in 6.3\%. Those authors observed an antagonism between $\mathrm{Zn}$ and $\mathrm{Cu}$, and found that $\mathrm{Zn}$ deposition in the yolk was significantly lower as copper increased and vice-versa. The enrichment of the eggs with the other elements was marginal $(\mathrm{Cu})$ or absent $(\mathrm{Zn})$.

The lack of increase in yolk mineral concentration in the present study, as opposed to the findings of
Skrivan et al. (2005), Mabe et al. (2003) Bertechini et al. (2000), and Paik (2001), may have been a function of the determination of dietary trace mineral levels, which interval may have been insufficient to express the potential effects of those trace minerals on the yolk.

\section{CONCLUSIONS}

Under the conditions of the present study, it was concluded that the level of $70 \%$ organic trace mineral supplement, as compared to $100 \%$ inorganic trace minerals, may be used in the diet of semi-heavy layers in their second cycle of lay with no changes in egg quality or yolk protein level and mineral composition.

\section{REFERENCES}

Association of Official Analytical Chemists - AOAC. Official methods of analysis. 16th ed. Washington; 1995. v.1-2.

Albuquerque, R. Produção e qualidade da casca de ovos de galinhas poedeiras recebendo microminerais orgânicos em sua dieta [tese]. Pirassununga (SP): Universidade de São Paulo; 2004.

Ammerman CB, Baker DH, Lewis AJ. Supplemental organically bound mineral compounds. In: Garnsworthy PC, Wiseman J, editors. Recents advances in animal nutrition. Nottingham: University Press; 1998. p.156-178.

Aoyagi S, Baker DH. Nutritional evaluation of a cooper-methionine complex for chicks. Poultry Science 1993; 72(12):2309-2315.

Baker DH, Odle J, Funk MA, Wieland TM. Bioavailability of copper in cupric oxide, cuprous oxide, and in a copper-lysine complex. Poultry Science 1991; 70(1):177-179.

Benites $\mathrm{Cl}$, Furtado PBS, Seibel NF. Características e aspectos nutricionais dos ovos. In: Souza-Soares LA, Siewerdt F. Aves e ovos. Pelotas: Ed. da Universidade UFPEL; 2005.

Bertechini AG. Mitos e verdades sobre o ovo e consumo. Anais da Conferência Apinco de Ciência e Tecnologia Avícolas; 2003; 


\section{Saldanha ESPB, Garcia EA, Pizzolante $C C$, Faittarone ABG, Sechinato A da, Molino AB, Laganá C}

Effect of Organic Mineral Supplementation on The Egg Quality of Semi-Heavy Layers in Their Second Cycle of Lay
Santos, São Paulo. Brasil. p.19-26.

Bertechini AG, Fassani EJ, Fialho ET, Spadoni JA. Iron supplementation for commercial laying hens in second cycle of production. Journal of Brazilian Poultry Science 2000; 2(3):267272.

Cao J, Luo XG, Henry PR, Ammerman, CB, Littell RC, Miles RD. Effect of dietary iron concentration, age and length of iron feeding on feed intake and tissue iron concentration of broiler chicks for use as a bioassay of supplemental iron sources. Poultry Science 1996; 75(4):495-504.

Card LE, Nesheim MC. Producion avicola. Zaragoza: Editoral Acribia; 1978.

Close WH. Biotechnology in the food industry: the role of trace mineral proteinates in pig nutrition. Proceedings of the 14 Alltech's Annual Symposium; 1998; Nottingham. Nottinghamshire. p. 376-469.

Correia GMG, Takata FN, Medeiros JP, Barros ACS, Aguiar JFC, Evêncio Neto J Efeito do tempo de armazenamento sobre a qualidade de ovos de aves tratadas com selênio orgânico. Revista Brasileira de Zootecnia 2000; 29(5):1440-1445.

Faria DE, Silva FHA, Rizzo MF, Sakamoto MI, Araújo LF, Junqueira OM Sólidos totais e rendimento dos componentes dos ovos de poedeiras brancas e marrons. Acta Science Animal Science 2007; 29(2):173-177.

Ferreira DN. Sistema de análise de variância para dados balanceados. Lavras: Ufla/Dex/Sisvar; 2000.

Franco JRG, Sakamoto MI. Qualidade de ovos: uma visão geral dos fatores que a influenciam. Ave World 2005; 3(16).

Klecker D, Zemar L, Siske V, Gomez BJ. Influence of trace mineral proteinate supplementation on eggshell quality. Poultry Science 1997; 76 (suppl 1):116-131.

Kuit AR. Genetic aspects of egg quality. Proceedings of the $17^{\circ}$ World's Poultry Congress ;1984; Helsinki, Finland. p. 47-50.

Lundeen T. Mineral proteinates may have positive effect on shell quality. Feedstuffs 2001; 73(14):10-15.

Mabe IC, Rapp M, Bain M, Nys Y. Supplementation of a cornsoybean meal diet with manganese, copper, and zinc from organic or inorganic sources improves eggshell quality in aged laying hens. Poultry Science 2003; 82(12):1903-1913.

Madrid AV, Cenzano J, Vicente JM. Manual de indústria dos alimentos. São Paulo: Varela; 1996.

Moreng RE, Balnave D, Zhang D. Dietary zinc methionine effect on eggshell quality of hens drinking saline water. Poultry Science 1992; 71:1163-1167.

Paik I. Application of chelated minerals in animal production. Journal of Animal Science 2001; 14:191-198.
Paton ND, Cantor AH. Effect of dietary selenium source and storage on internal quality and shell strength of eggs. Poultry Science 2000; 70 (Supl. 1):116.

Rose SP. Principles of poultry science. New York: CAB International; 1997.

Rostagno HS, Albino LFT, Donzele JL, Gomes PC, Ferreira AS, Oliveira RF, Lopes DC. Tabelas brasileiras para aves e suínos: composição de alimentos e exigências nutricionais. 2 ed. Viçosa (MG): Universidade Federal de Viçosa; 2000.

Rutz F, Pan EA, Xavier GB. Efeito de minerais orgânicos sobre o metabolismo e desempenho de aves. 2006 [cited 2006 jul 6]. Available from: http://www.aveworld.com.br/index.php? documento $=141$

Scatolini AM. Mn, Zn e Se associados a moléculas orgânicas na alimentação de galinhas poedeiras no segundo ciclo de produção [dissertação]. Jaboticabal (SP): Universidade Estadual Paulista; 2007.

Sechinato AS. Efeito da suplementação dietética com microminerais orgânicos na produção e qualidade de ovos de galinhas poedeiras [dissertação]. Pirassununga (SP): Universidade de São Paulo; 2003.

Skrivan M, Skrivanova V, Marounek M. Effects of dietary zinc, iron, and copper in layer feed on distribution of these elements in eggs, liver, excreta, soil, and herbage. Poultry Science 2005; 84:1570-1575.

Souza PA, Faleiros RRS, Souza HBA. Efeitos sobre a qualidade dos ovos. Avicultura Industrial 1984; 893:24-27.

Spears JW, Schoenherr WD, Kegley EB, Flowers WL, Alhunsen HD. Efficacy of iron methionine as a source for iron for nursing pigs. Journal of Animal Science 1992; 70 (Supl. 1):243.

Vieira, SL. Minerais quelatados na nutrição animal. Anais do Simpósio Sobre Manejo e Nutrição de Aves e Suínos; 2004; Campinas, São Paulo. Brasil. p.51-70.

Xavier GB, Rutz F, Dionello NJL, Duarte AD, Gonçalves FM, Zauk NHF, Ribeiro CLG. Performance of layers fed diets containing organic selenium, zinc and manganese, during a second cycle of production. Proceedings of the $20^{\circ}$ Annual Symposium on Biotechnology in the Feed Industry; 2004; Lexington, Kentucky, EUA. p.19. 


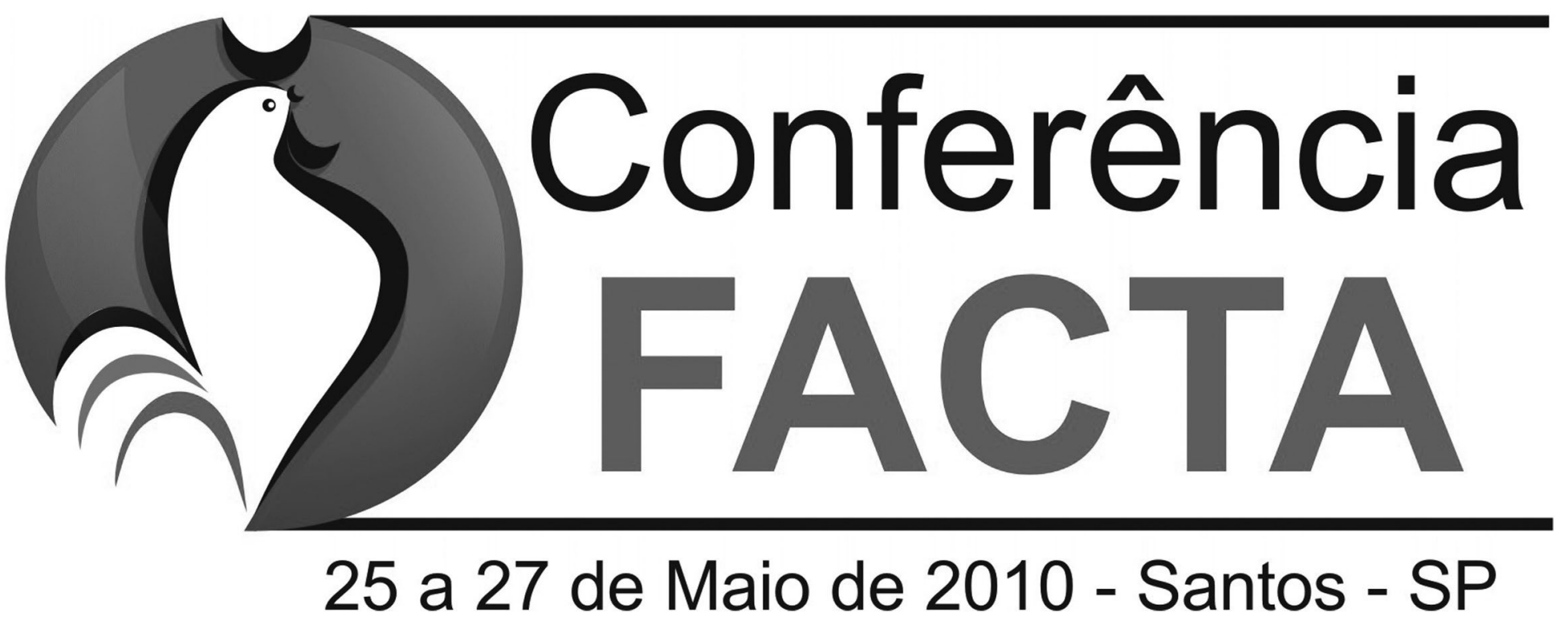

\author{
Informações: \\ e-mail: facta@facta.org.br \\ site: www.facta.org.br
}

